УДК 339.94.73

JEL classification: L90, M11,M13

Солнцев С.O.

доктор фіз.-мат. наук, професор, ORCID ID 0000-0002-8820-3528

Жигалкевич Ж.М.

канд. економ. наук, дочент ORCID ID 0000-0002-5847-1302

Наиіональний технічний університет України

«Київський політехнічний інститут імені Ігоря Сікорського»

\title{
ФАКТОРИ ФОРМУВАННЯ ТА КЛАСИФІКАЦІЯ КВАЗІІНТГРАЦІЙНИХ СТРУКТУР
}

\section{ФАКТОРЫ ФОРМИРОВАНИЯ И КЛАССИФИКАЦИЯ КВАЗИИНТЕГРАЦИОННЫХ СТРУКТУР}

\section{FACTORS OF FORMATION AND CLASSIFICATION QUASI-INTÉGRATION STRUCTURES}

Зроблено спробу визначити фактори формування квазіінтеграційних структур та класифікувати їх. На основі вивчення фахової наукової літератури виділено загальні причини необхідності створення інтегрованих структур. Подано авторське визначення понять «квазіінтегариія» та «квазіінтеграчійна структура». На основі аналізу існуючих наукових підходів та власних спостережень виявлено визначальні фактори створення квазіінтегрованих структур. Подано визначення та характерні ознаки загальновизнаних форм прояву квазіінтеграційних структур, серед таких: стратегічні альянси, пеtwork об'єднання, кластери, ланцюжок (мережа) створення цінності, фоккальні мережі поставок, динамічні фокальні мережі, віртуальні організаџії (авторське визначення). Зазначено, що важливими аспектами класифікачії квазіінтегаційних структур є: причинні, структурно-функціональні та технологічні ознаки. Згідно виявлених ознак та характеристик кожної форми прояву квазіінтеграчії запропоновано сукупність критеріїв їх класифікації. Виявлено причини труднощзів створення квазіінтеграційних структур.

Ключові слова: інтеграція, квазіінтеграція, квазіінтеграційна структура, фактори, форми, класифікація.

Сделана попытка определить факторы формирования квазиинтеграчионные структуры и классифицировать их. На основе изучения профессиональной научной литературы определены общие причины необходимости создания интегрированных структур. Представлено авторское определение понятий «квазиинтегариия» $u$ «квазиинтеграџийна структура». На основе анализа существующих научных подходов $и$ собственных наблюдений выявлены определяющие факторы создания квазиинтегрованих структур. Даны определения и характерные признаки общепризнанных форм проявления квазиинтеграчийних структур, среди которых: стратегические альянсы, network объединения, кластеры, цепочка (сеть) создания ценности, фокальные сети поставок, динамические фокальные сети, виртуальные организации (авторское определение). Отмечено, что важными аспектами классификации квазиинтегацийних структур являются: причинные, структурно-функцииональные и технологические признаки. Согласно 
выявленных признаков и характеристик каждой формы проявления квазиинтеграция предложена совокупность критериев их классификации. Выявлены причины трудностей создания квазиинтеграционных структур.

Ключевые слова: интеграция, квазиинтеграция, квазиинтеграцийна структура, факторы, формы, классификация.

In this article was made an attempt to identify factors that form quasi-integration structures and classify them. On the basis of professional scientific literature, this article identifies common reasons for the need to create integrated structures. There is also presented the author's definition of the concepts of "quasi-integration" and "quasi-integration structure". Based on an analysis of existing scientific approaches and our own observations revealed determinants of creating quasi-integration structures. The definitions and the characteristics of the universally recognized forms of expression quasi-integration structures, such as: strategic alliances, the Network associations, clusters, chain (network) of the value, the focal supply chain, dynamic focal network, virtual organizations. It is noted that the important aspects of classification quasiintegration structures are causal, structural-functional and technological features. According to the identified attributes and characteristics of each form of manifestation quasi-integration, there was proposed set of criteria for their classification. In this article were also found out the reasons that cause difficulties of creation quasi-integration structures.

Keywords: integration, quasi-integration, quasi-integration structure, factors, shapes, classification.

Вступ. Процеси глобалізації вплинули на розвиток мережевої співпраці. Сучасна конкуренція на ринку пов'язана 3 питаннями доступу не тільки до ресурсів, а й до інформації та бізнес-партнерів. Досвід успішних компаній свідчить, що результативність взаємодії бізнес-суб'єктів збільшується при формуванні і розвитку інтеграційних процесів у межах мережевих об'єднань. Однак методологія формування цих утворень в умовах економіки України залишається недостатньо розкритою. Зокрема фактори формування квазіінтегаційних структур знаходиться на стадії активного вивчення.

Питаннями формування та функціонування інтеграційних структур досліджували класики економічної науки: А. Маршалл, Й. Шумпетер, О. Уільямсон, Е. Чемберлін та інші. Серед сучасних вчених роботи зазначені проблеми висвітлено у роботах: М. Портера, Ю. Паппэ, Б. Клейнера, О. Булатова, Д. Стеченка, 3. Варналія.

Проблемам квазіінтеграціїі приділено увагу в незначній кількості робіт: К. Дж. Блуа, Б. Ашеіма, Дж. К. Джарилло, Д. Дж.Тиса, В. Дементьєва, В. Третьяка М. Шерешевої, М. Янчук та інших. Але дослідники мають розбіжності як у визначеннях, так і в сприйнятті зазначених структур. 3 огляду на зазначене подане дослідження актуальне та своєчасне.

Постановка завдання. Метою дослідження $є$ виявлення факторів формування квазіінтеграційних структур, розкриття визнаних форм квазіінтеграції та їх класифікація. 
Методологія. Теоретико-методологічною основою проведеного дослідження стали загальнонаукові методи наукового пізнання: монографічний, теоретичного узагальнення, порівняння, систематизації, аналізу та синтезу.

Результати дослідження. Досвід розвинутих індустріальних країн свідчить про те, що саме інтегровані структури є каркасом економіки. Розвиток інституційних структур світової та національних економічних систем орієнтується на посилення інтеграційних процесів. Сутність останніх полягає в встановленні довгострокових партнерських зв'язків між взаємодіючими суб'єктами господарювання.

Вивчення наукової фахової літератури 3 організаційних процесів та теорії організації надало можливість виділення загальних причин необхідності створення інтегрованих структур:

- стихійність міжфірмових взаємовідносин;

- загострення конкуренції;

- невизначеність зовнішнього середовища;

- посилення ролі інформаці;

- значення фактору часу;

- зростання числа пропонованих продуктів і послуг при одночасному зниженні їх життєвих циклів;

- зростання темпів інновацій разом із технологічними змінами;

- поява нових форм взаємозв'язків та необхідність розвитку сітьового маркетингу;

- необхідність адаптивності та швидкісної реакції на зміну ринкової кон'юнктури;

- можливість концентрації діяльності кожного 3 учасників на найкращих компетенціях і унікальних процесах;

- істотне скорочення витрат, формування їх раціональної структури;

- можливість залучення до спільної діяльності в рамках мережі оптимальних партнерів, виключення використання другосортних виконавців [1-3].

Концепція поданого дослідження полягає у дослідженні гібридної форми інтеграції - квазіінтеграції.

Квазіінтеграція — це формальне (уявне) об'єднання на договірній основі, що залишає самостійність суб'єктів, які входять до його складу.

Квазіінтеграційна структура - це добровільне просторове партнерське сполучення взаємодіючих виробництв та наукових (науково-дослідних, науково-технологічних, науково-технічних, науково-практичних) установ на засадах комплексного використання наявних ресурсів, спрямованих на досягнення найбільшої господарської ефективності та посилення ринкових позицій, особливістю якого є відсутність контролю над власністю активів [4]. 
На основі аналізу існуючих наукових підходів та власних спостережень до визначальних факторів створення квазіінтегрованих структур віднесено наступні:

- орієнтація сучасної економіки на економіку знань, що пов'язана 3 кваліфікацією та професійною підготовленістю і розвитком творчих навичок кадрового потенціалу;

- орієнтація на інформаційний простір;

- спрямованість на контекстні фактори економіки: час, влада, масштаб, збереження, можливості, потенціал;

- урахування нових ринкових вимог (або ринкові фактори);

- мінливість зовнішнього середовища;

- реалізація технологічних укладів;

- впровадження підривних технологій;

- актуалізація міжфірмових партнерських взаємин;

- передбачення (форсайту), як основа запобігання ризиків та невизначеності у прийнятті управлінських рішень;

- отримання синергетичних ефектів [5].

В існуючих дослідженнях щодо форм прояву квазіінтеграційних структур погляди науковців мають певні розбіжності. Серед загальновизнаних структур: стратегічні альянси, Network-об'єднання, кластери, ланцюжок (мережа) створення цінності, фокальні мережі поставок, динамічні фокальні мережі, віртуальні організації.

Кожна 3 зазначених форм квазіінтеграції має свою еволюцію становлення та характерні ознаки.

Стратегічний альянс - угода про кооперацію двох або більше незалежних фірм для досягнення певних комерційних цілей, спрямованих на отримання синергії об'єднаних і взаємодоповнюючих стратегічних ресурсів компаній [6].

Характерними ознаками стратегічних альянсів визнано:

- володіння гігантською ринковою владою;

- закритість, оскільки специфічне поєднання партнерів виступає одним з головних конкурентних переваг;

- можливість зумовити глибокі зміни в структурі галузевого ринку, що призводить, до виникнення конкуренції між альянсами;

- переважна впливовість однієї або двох компаній;

- присутність центральної керуючої одиниці;

- збіжність тільки деяких цілей контрагентів i, найчастіше, тільки на певний відрізок часу, при цьому партнери по альянсу часто залишаються конкурентами в усіх сферах діяльності, які не стосуються спільно переслідуваної мети. 
До наступного типу квазіінтеграції віднесено Network-об'єднання. Це вільна гнучка коаліція, керована з єдиного центру, яка бере на себе виконання таких важливих функцій, як створення мереж і управління ними, координацію фінансових ресурсів і технологій, визначення сфер компетенцій та стратегії, а також вирішує відповідні питання управління, що зв'язують мережу воєдино інформаційними ресурсами [7].

До особливостей Network- об'єднань можна віднести:

- формуються з середніх фірм, що мають значну ринкову владу;

- результат взаємодії між учасниками мережі відбувається через створення бізнес-структури;

- створюється на основі «м'якої» інтеграції між учасниками;

- базується на розвитку мережевої співпраці, що заснована на формальних та неформальних відносинах та прямих зв'язках;

- одним з принципів $є$ партнерство серед учасників

- відсутність обмежень діяльності фірми, бюрократичного контролю і системи координації діяльності;

- високі оперативність, швидкість і темп діяльності;

- нечутливість до локальних конкурентним поразок;

- можливість об'єднання, комбінування i рекомбінування знань i досвіду;

- висока інформованість про стан ринку та положення мережі.

Нині активну роль в інтегруванні підприємств відіграє кластерна квазіінтеграція.

Кластер - група, агломерація підприємств, поєднаних географічно та економічними інтересами, метою яких є підвищення ефективності діяльності та конкурентоспроможності.

Найбільш характерними ознаками організаційних форм кластерів наступні:

- утворюються з дрібних фірм, що не володіють ринковою владою;

- географічна концентрація;

- множинність економічних агентів;

- функціональна взаємопов'язаність і взаємодія учасників;

- спеціалізація фірм-суб'єктів кластера;

- присутність конкуренції всередині кластера;

- інноваційна направленість;

- наявність висококваліфікованого персоналу.

Ще однією формою квазіінтеграції $є$ ланцюжок (мережа) створення цінності - форма вертикальної квазіінтеграції, особливою ознакою якої $\epsilon$ довгострокове співробітництво партнерів, що мають в цілому рівні права $\mathrm{i}$ розташованих уздовж ланцюжка створення цінності, обслуговуючи специфічні ринки або замовлення клієнтів [3]. 
Основними характеристиками, що притаманні ланцюжку створення цінності, як форми прояву квазіінтеграції, наступні:

- створюється 3 партнерів наділених рівними правами (поліцентричність) та обслуговують специфічні ринки або закази клієнтів;

- взаємодія відбувається по вертикалі;

- співробітництво засновано на збереженні конкурентних переваг ланцюжка, особливо з налагодження процесів і обробки інформації;

- орієнтація на створення кращих умов доступу на ринок і скорочення часу на адаптацію до умов, що змінюються запитами споживачів;

- основна мета - пошук нових підходів, що створюють додаткові вигоди.

На основі поліцентричного ланцюжку створення цінності виникає фокальна мережа поставок - мережа, в якій одна (як правило, велика) компанія $\epsilon$ центральною одиницею (фокальною фірмою), а постачальники, розташовані на різних сходинках створення цінності (постачальники першого, другого, третього рівнів), знаходяться в залежному становищі [8]. Особливостями створення якої є:

- присутність центральної (фокальної) одиниці, що координує діяльність всієї мережі;

- формуються компаніями-виробниками, що володіють значною ринковою владою у своїй галузі;

- мають чітко формалізовану організаційну структуру;

- присутній технологічний диктат та безперервний аудит якості;

- закритість входу у структуру для аутсайдерів.

Ще однією похідною ланцюжку створення цінності є динамічна фокальна мережа - вертикальна мережа, що забезпечує створення цінності для споживача, комбінуючи продукти i послуги компаній-партнерів, згрупована навколо однієї домінуючою центральної одиниці, яка координує діяльність по створенню цінності ієрархічними методами [8]. ÏÏ характеристики:

- наявність домінуючої центральної одиниці;

- відсутність стабільності, тобто структура досить динамічна та гнучка;

- присутність динамічної внутрішньої конкуренції;

- відкритість входу у структуру для аутсайдерів;

- прагнення до збільшення сукупного розміру мережі.

Розвиток інформаційних технологій і глобалізація бізнесу зумовили виникнення нових підходів до формування квазіінтеграційних структур, а саме створення віртуальних організацій.

Авторами ж поданого дослідження вважається, що віртуальна організація - це динамічна адаптивна квазіінтеграційна структура 3 розвинутою віртуальною мережевою платформою, яка створює та постачає на 
ринок споживчу цінність, засновану на виявленні і швидкісному виконанні потреб клієнтів 3 певними конкурентними перевагами, використовуючи ресурси підприємств-учасників та зберігаючи їх повну автономність та конкуренцію в межах утворення.

До специфічних ознак побудови віртуальних організацій можна віднести:

- наявність розвинутої віртуальної платформи, що заснована на використанні інформаційних та комп’ютерних технологій;

- здатність послідовно отримувати та координувати критично важливі компетенції;

- мінливість, тобто здатність включати різних зовнішніх партнерів до процесу створення цінності;

- спосіб структурування та управління діяльністю, що спрямована на досягнення мети за допомоги грамотного вибору виконавців, які найбільш адекватно відповідають абстрактним потребам завдання;

- поліцентричність (партнери в основному мають приблизно рівні права) і відкритість входу в структуру;

- спільне використання вмінь і досвіду, розподілення витрат і сприяння одна другій в доступі на засвоєні ними ринки.

Вибір форми квазіінтергації майбутніми корпоративними структурами буде заснований на зіставленні їх характерних ознак та визначенні, які саме відповідають меті створення.

Для проведення класифікації квазіінтегаційних структур вважається, що важливими аспектами є причинні (передумови, умови та стадії формування), структурно-функціональні (поєднання підгалузей, виробництв, спеціалізація) та технологічні (завершеність виробництва, його взаємозв'язок) ознаки. Їх об'єднують три взаємопов'язані наукові підходи до типології - просторовий, економічний і технологічний.

Згідно виявлених ознак та характеристик кожної форми прояву квазіінтеграції запропоновано сукупність критеріїв їх класифікації:

1) за формою прояву: стратегічний альянс; Network об'єднання; кластер; ланцюжок створення цінностей; фокальна мережа; динамічна фокальна мережа; віртуальна організація;

2) за характером територіального розміщення: локальні; регіональні; національні; транскордонні; міжнародні; глобальні;

3) за складом і галузевою структурою: галузеві; міжгалузеві;

4) за найважливішими факторами формування орієнтовані на: економіку знань; інформаційний простір; контекстні фактори економіки; нові ринкові вимоги; динамічні здібності; реалізацію технологічних укладів; впровадження підривних технологій; встановлення міжфірмових партнерських взаємин; форсайт; синергетичних ефектів; 
5) за функцією створення: інвестиційні; виробничі; збутові; дослідницькі; фінансові; інноваційно-технологічні;

6) за видом зв'язків між галузями, підприсмствами і виробництвами: виробничо-технологічні; техніко-економічні; організаційно-економічні; партнерські; комерційні; ресурсні;

7) за складом учасників: сировинні; фінансово-виробничі; торгівельновиробничі; виробничі;

8) за особливістю відносин між учасниками кваїнтеграційної структури: управлінські, засновані на централізації ресурсів; централізація постачання i збуту; координація за допомогою кредитів, фінансовоінвестиційних, страхових та лізингових послуг; регулювання доступу до інформаційних ресурсів і нових технологій; спільне заснування і використання необхідних ринкових структур; управління постачанням i збутом;

9) за стійкістю взаємозв'язків: довгострокові стійкі зв'язки; короткострокові зв'язки (об'єднання для спільного кредитування та реалізації конкретних проектів);

10) за типом взаємозв'язків: відносини «один до багатьох»; відносини «багато до одного»; вертикальна; горизонтальна; радіальна; кругова;

11) за типом господарської взаємодії: матеріальні взаємодії; фінансові взаємодії; інформаційні взаємодії;

12)за кількістю мозкових центрів: моноцентричні; біцентричні; поліцентричні;

13) за способом утворення: ініційовані; природні;

14) за ијільовими установками: зростання виробництва в межах існуючої номенклатури; економія фінансових витрат; витіснення конкурентів; проведення НДДКР; виробництво інноваційної продукції; впровадження підривних технологій.

15) за типом поведінки на ринку: захисні; агресивні;

16) за типом управління: керівний комітет; управляюча компанія;

17) за рівнем розвитку сфери діяльності: розвинуті; які розвиваються; нерозвинуті.

18)за ступенем рівноправності взаємин: наявність домінуючої центральної одиниці; поліцентричні.

19) за структурою: об'єднання малих та середніх підприємств; формування 3 ядром із великих компаній; засновані на взаємодії великої кількості замовників та виконавців, що потребує розвиненого ринку субконтрактації;

20) за організаційною формою: неформальні - 3 вільними відносинами між учасниками; організовані - у формі структурованого співробітництва; 
21) за характером домінуючих взаємозв'язків засновані на: виробничотехнологічних зв'язках; техніко-економічних зв'язках; організаційноекономічних зв'язках;

22) за ступенем диверсифікаиії діяльності спрямовані на випуск: одного виду інноваційної продукції; різноманітних видів інноваційної продукції;

23)за рівнем інформачійно-комунікаційного забезпечення: слаборозвинуті; розвинуті;

24) за укомплектованістю інфраструктури: неповні; досконалі;

25) за рівнем забезпеченості кадровим потенціалом: слабозабезпечені; забезпечені;

26) за реалізацією проектів: наукові; освітні; соціальні; екологічні; венчурні; інноваційні;

27) за розміром: малі - включають до 50 організацій; середні - від 50 до 200 організацій; великі - понад 200 організацій;

28) за строком існування: короткострокові; довгострокові

Подана класифікація квазіінтеграційних структур дозволяє визначити, належить або не належить об'єкт до того чи іншого класу, та здійснювати «прив'язку» типу інтеграції до конкретного типу квазіінтеграційної стратегії.

Висновки. Наукова новизна поданих результатів полягає у наступному: подано авторські поняття «квазіінтеграційна структура», «віртуальна організація»; виявлено фактори формування квазіінтеграційних структур; запропоновано сукупність критеріїв класифікації квазіінтеграційних структур.

Отже, спроби виявити фактори, форми та класифікаційні ознаки квазіінтеграційних структур зумовлено певними труднощами. Причиною цьому $\epsilon$ значні розбіжності в емпіричних дослідженнях, описаних в зарубіжній і вітчизняній фаховій літературі та відсутністю в науковому середовищі консенсусу щодо змістовних характеристик різних форм квазіінтеграційних структур взаємодіючих підприємств. Зазначене зумовлює необхідність проведення теоретичних та науково-методичних досліджень зорієнтованих на дослідження закономірностей та принципів їх утворення.

\section{Лiтература:}

1. Richardson G.B. The Organisation of Industry. G. B. Richardson. The Economic Journal, Vol.82, No. 327 (Sep.,1972)

2. Osborn R., Hagedoorn F. The Institutionalization and Evolutionary Dynamics of Interorganizational Alliances and Networks, Academy of Management Journal. 1997. Vol. 40. No. 2.

3. Шерешева, М.Ю. Формы сетевого взаимодействия компаний. Курс лекций : учеб. пособие / М. Ю. Шерешева. - М. : Изд. дом Гос. ун-та — Высшей школы экономики. 2010. - $339 \mathrm{c}$.

4. Квазіінтеграція взаємодіючих підприємств: теоретичний аспект [Електронний ресурс] / С.О.Солнцев, Ж.М.Жигалкевич // Глобальні та національні проблеми економіки [електронне наукове фахове видання] — Електрон. журн. - Миколаїв : МНУ, 2016. - 
Вип. 12. - Режим доступу : http://global-national.in.ua/archive/12-2016/71.pdf. - Заголовок з екрану.

5. Розвиток ринкових відносин на основі квазінтеграції / С.О.Солнцев, Ж.М.Жигалкевич // Вісник НУ “Львівська політехніка” . Серія : Логістика. — № 846. — 2016. - С.159-164.

6. Старовойтов М.К. Управленчиские решения в современных организациях: теория и практика [Электронный ресурс]: учеб.пособие / М.К.Старовойтов, Л.Н.Медведева, Е.В.Гончарова Я.М.Старовойтова, Г.И.Лукьянов // Сборник «Учебные пособия» Выпуск 5. - Электрон.текстоввые дан. (1 файл: 2,35 МБ) - Волжский ВПИ (флиал) ВолгГТУ, 2014 г. - Режим доступа: https://books.google.com.ua/books?id=NuGpCgAAQBAJ

7. Webser, J. Networks of Collaboration or Conflict? Electronic Data Interchange and Power in the Supply Chain / J. Webser // The Journal of Strategic Information Systems. - 1995. - Vol. 4. - № 1. - P. $31-42$.

8. Орехова С.В. Межфирменные сети: сущность, виды, преимущества [Электронный pecypc] - Заголовок с экрана. — Режим доступа : http://orekhovasv.ru/Is_PDF/C/C3.pdf 